\title{
PENGARUH KUALITAS PELAYANAN PENGELOLAAN KAWASAN TERHADAP KEPUASAN PELANGGAN KAWASAN SCBD JAKARTA
}

\author{
Gregorius Gerard $^{1}$, Nurahma Tresani ${ }^{2}$, Nasiruddin Mahmud ${ }^{3)}$ \\ 1)Program Studi S2 PWK, Fakultas Teknik, Universitas Tarumanagara, gregorius.agra@gmail.com \\ 2)Program Studi S2 PWK, Fakultas Teknik, Universitas Tarumanagara, ntresani@gmail.com \\ ${ }^{3)}$ Program Studi S2 PWK, Fakultas Teknik, Universitas Tarumanagara, nasir.prodeva@gmail.com
}

Masuk: 01-01-2021, revisi: 22-02-2021, diterima untuk diterbitkan: 28-03-2021

\begin{abstract}
Abstrak
Perekonomian Global memiliki dinamika yang sangat tinggi dalam 5 tahun terakhir, mulai dari munculnya Masyarakat Ekonomi ASEAN (MEA), berkembangnya perekonomian digital, serta bertumbuhnya platform perekonomian digital yang antara lain dipacu oleh adanya pandemi COVID-19. Namun kondisi perekonomian yang tidak stabil, mendorong respon perusahaan untuk semakin peka terhadap kebutuhan konsumen dan tanggap menghadapi perubahan dalam pasar. SCBD sebagai salah satu CBD Jakarta tentunya turut terdampak secara perekonomian. Pengelola kawasan SCBD mempunyai kewajiban dan tanggung jawab untuk menjaga kawasan agar dapat beroperasi dengan baik pada situasi dan kondisi saat ini. Kualitas pelayanan merupakan komponen penting bagi perusahaan untuk dapat bertahan dalam bisnis. Penilitian ini bertujuan untuk mengetahui pengaruh kepuasan pelayanan pengelolaan kawasan terhadap kepuasan pelanggan Kawasan SCBD Jakarta dengan metode Customer Satisfaction Index (CSI). Penelitian menunjukkan nilai CSI Kawasan SCBD tetap berada dalam kategori memuaskan pada kondisi saat ini, namun hal tersebut tetap perlu dipertahankan dengan tetap menjaga performa serta memperbaiki faktor-faktor yang masih perlu ditingkatkan. Terkait adanya pandemi, faktor penanganan COVID-19 tetap perlu dipertahankan. Selain itu perlu adanya pembahasan lebih lanjut terkait kegiatan operasional yang efektif dan efisien tanpa mengorbankan kenyamanan pelanggan. Hal tersebut dilakukan agar kepercayaan masyarakat untuk dapat beraktivitas kembali di SCBD seperti sediakala dapat terbangun kembali.
\end{abstract}

Kata kunci: CBD; CSI; kawasan; kepuasan; pelanggan; pengelola; SCBD

\begin{abstract}
The global economy had been running dynamical in the last 5 years. Since, the emergence of the ASEAN Economic Community (AEC). COVID-19 also generate growth of digital economy platform. Unstable economic conditions have prompted the company's response to be more sensitive to consumer needs and responsive to changes in the market. SCBD as one of market leader in Jakarta's CBD estate management Jakarta's CBD. The management of the SCBD area has responsibility operate the area properly and protect the area in the current situation and conditions. Service quality is an important component for a company. This study aims to determine the effect of area management service satisfaction on customer satisfaction in the SCBD Jakarta area using the Customer Satisfaction Index (CSI) method. Research shows that the CSI value of the SCBD area remains in the satisfactory category, but it still needs to be maintained while maintaining performance and improving the factors that still need to be improved. Regarding the pandemic, the factor of handling COVID-19 still needs to be maintained. In addition, there is a need for further discussion related to effective and efficient operational activities without sacrificing customer comfort. So, public trust can be improve and the activities in SCBD can be return as before.
\end{abstract}

Keywords: CBD; customer; estate; management; satisfaction; SCBD 


\section{PENDAHULUAN}

\section{Latar Belakang}

Perekonomian Global memiliki dinamika yang sangat tinggi dalam 5 tahun terakhir, mulai dari munculnya Masyarakat Ekonomi ASEAN (MEA), berkembangnya perekonomian digital, serta bertumbuhnya platform perekonomian digital yang antara lain dipacu oleh adanya pandemi COVID-19. Globalisasi tidak dapat dielakkan, potensi pergerakan keluar-masuk tenaga kerja asing akan meningkat, terutama di negara ASEAN yang masih memiliki ruang berkembang yang sangat luas. Namun kondisi perekonomian yang tidak stabil, mendorong respon perusahaan untuk semakin peka terhadap kebutuhan konsumen dan tanggap menghadapi perubahan dalam pasar.

Total pasokan Komersial Space SCBD mencapai 1.737.498 M2. SCBD telah mengembangkan dan mengelola kawasan menjadi pusat bisnis premium dengan gedung perkantoran, hunian eksklusif, pusat perbelanjaan modern dan hotel bintang lima, yang didukung dan dilengkapi dengan sarana dan prasarana yang terintegrasi. Pengelola Kawasan SCBD mempunyai kewajiban membantu Pemerintah DKI Jakarta dalam mengendalikan pelakasanaan pembangunan di dalam Kawasan SCBD, melaksanakan dan membiayai pengoperasian prasarana dan fasilitas umum serta kebersihan di dalam ruang umum kawasan SCBD, membuat Peraturan Kawasan sesuai dengan kebutuhan untuk tercapainya pengelolaan Kawasan SCBD yang sebaik-baiknya dengan tetap mengacu kepada ketentuan Perundangundangan yang berlaku dan melaksanakan pengawasan kawasan SCBD.

Berdasarakan analisa pasar properti triwulan Cushman Wakefield, COVID-19 mempengaruhi semua sektor bisnis, terjadi pengurangan karyawan, relokasi, dan penutupan kantor. Hal tersebut banyak terjadi pada gedung-gedung perkantoran di Central Business District (CBD). Pengelola kawasan SCBD mempunyai kewajiban untuk menjaga kawasan agar tetap dapat beroperasi dengan baik pada situasi dan kondisi saat ini. Kualitas pengelolaan kawasan merupakan poin penting dalam upaya mempertahankan posisi sebagai market leader.

\section{Rumusan Permasalahan}

SCBD sebagai salah satu market leader di sektor real estat properti dan pengelolaan kawasan tentu perlu mengevaluasi kembali posisinya di masa pandemi ini. Kualitas pelayanan merupakan komponen yang penting bagi perusahaan untuk tetap bertahan di situasi sulit saat ini dan tetap mempertahankan posisi market leader. Oleh karena itu perlu adanya evaluasi mengenai pelayanan pengelolaan kawasan SCBD, yang dapat dirumuskan sebagai berikut:

a. Bagaimana kualitas pelayanan pengelolaan kawasan SCBD?

b. Bagaimana kepuasan tenant di kawasan SCBD?

c. Bagaimana pengaruh kualitas pelayanan pengelolaan kawasan terhadap kepuasan tenant di kawasan SCBD?

\section{METODE PENELITIAN}

Obyek penelitian ini adalah Kawasan SCBD Jakarta. Pendekatan yang dipilih adalah pendekatan kuantitatif dan metode penelitian yang dipilih adalah metode analitik. Penelitian bertujuan untuk mengetahui pengaruh pelayanan pengelolaan kawasan terhadap kepuasan pelanggan Kawasan SCBD. Pengumpulan data dilakukan dengan menyebarkan kuesioner mengenai faktorfaktor pelayanan pengelolaan kawasan kepada 22 manager tenant tetap dan 13 manager tenant temporer yang mewakili seluruh populasi di SCBD. Untuk mendapatkan penilaian dari pengunjung, sampel yang diambil adalah sampel minimum yaitu 30 responden. Customer Satisfaction Index (CSI) dipilih sebagai metode analisis penelitian untuk mengetahui kinerja, kepentingan, dan kepuasan pelanggan itu sendiri. Konversi terhadap penilaian pelanggan 
perkantoran terhadap faktor- faktor yang menjadi obyek pelayanan dilakukan sebagai cara untuk mengetahui dan memetakan keadaan pada kondisi dan situasi saat ini.

\section{HASIL DAN PEMBAHASAN}

\section{Gambaran Umum Kawasan Sudirman Central Business District (SCBD)}

Secara administratif Sudirman Central Business District (SCBD) seluas +45 hektar, terletak di Jalan Jenderal Sudirman, Kelurahan Senayan, Kecamatan Kebayoran Baru, Kota Jakarta Selatan dengan koordinat 6o13'36.86"S 106048'35.35"E. SCBD merupakan kawasan superblock pusat perkantoran, pusat perbelanjaan dan entertainment, serta hunian dan penginapan bertingkat modern terletak di jantung kota Jakarta, antara Jalan Jenderal Sudirman, Jalan Jenderal Gatot Subroto dan Jembatan Semanggi. Fasilitas sosial dan fasilitas umum yang sudah dibangun di kawasan, antara lain jalan raya, jaringan air, listrik dan telekomunikasi, saluran pembuangan air kotor, taman, trotoar dan fasilitas lainnya. Pada saat ini di SCBD terdapat 30 lot terintegrasi, beberapa lot tower sudah terbangun sesuai dengan fungsi pemanfaatannya. Saat ini terdapat 35 gedung pada seluruh lot di SCBD, terdiri dari 22 gedung tenant tetap dan 13 gedung pemanfaatan sementara tenant temporer.

\section{Gambaran Umum Survey Kepuasan Pelanggan}

Kuesioner terdiri dari 9 faktor penilaian mengenai pelayanan yang perlu diisi dalam skala likert yaitu terdiri dari tidak puas, kurang puas, biasa saja, puas, dan sangat puas. Faktor penilaian tersebut meliputi kebersihan, keindahan, kenyamanan, kemudahan, keamanan, keselamatan, keberlanjutan, pencegahan COVID-19 yang dirumuskan berdasarkan skema berikut.

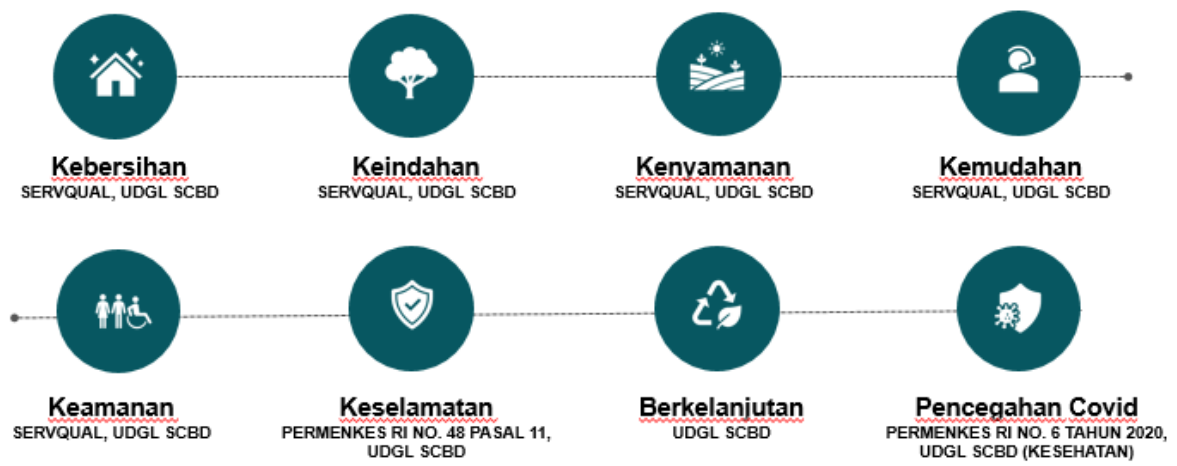

Gambar 1. Faktor Penilaian dan Literatur Sumber: Analisis Penulis, 2020

Pencapaian survey sebesar 65 responden yang terdiri dari 22 responden mewakili building manager (34\%), 13 responden mewakili temporary tenant manager (20\%), dan 30 responden mewakili visitor (46\%). Usia responden terbanyak adalah 25-34 tahun dengan persentase 52\%. Sedangkan untuk persentase jumlah pria sebesar $46 \%$ dan wanita sebesar $53 \%$. Jumlah responden tersebut sudah mewakili pendapat setiap building manager dan temporary tenant manager dari masing-masing gedung.

\section{Uji Reabilitas dan Uji Validitas}

Uji reabilitas dilakukan dengan menggunakan tools data analysis Excel. Apabila tingkat reliabilitas instrumen di atas 0.6 maka instrumen tersebut reliable. Berdasarkan data yang diuji nilai yang didapat 0.712 , maka instrumen ini reliable.

Gambar 2. Uji Reabilitas

Sumber: Olahan Data Penulis, 2020 
Uji validitas dilakukan dengan menggunakan tools data analysis Excel. Dalam tabel akan keluar angka $r$ hitung, kemudian untuk $r$ table berdasarkan product moment untuk $N$ (jumlah responden) sebanyak 65 dan taraf signifikansi $5 \%$ adalah 0,244 . Apabila $r$ hitung lebih dari $r$ table maka dinyatakan valid. Berdasarkan tabel pengolahan semua soal yang diuji telah valid.

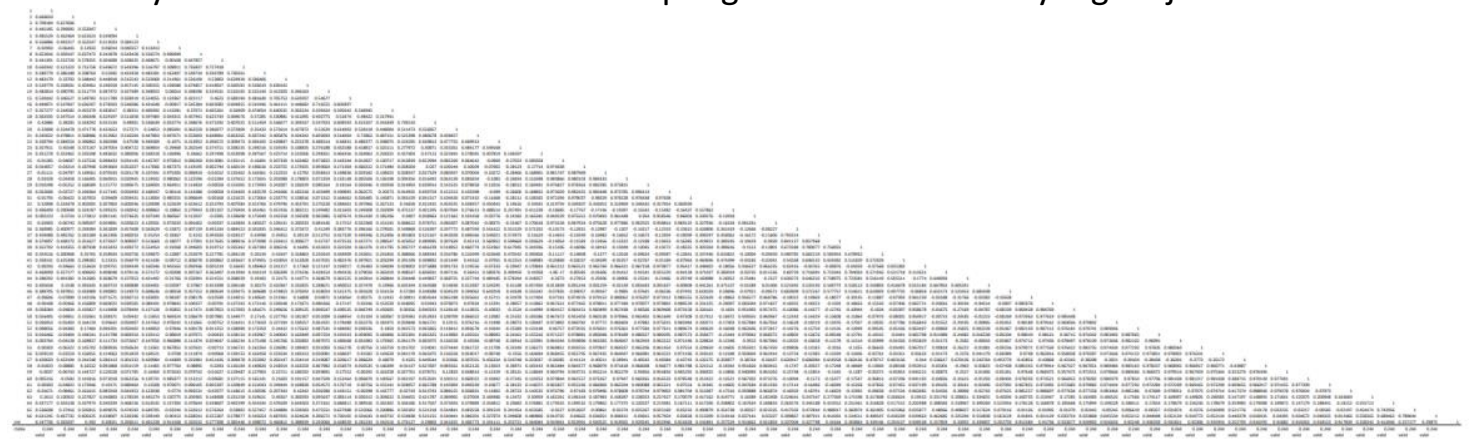

Gambar 3. Uji Validitas

Sumber: Olahan Data Penulis, 2020

\section{Customer Satisfaction Index}

Metode Customer Satisfaction Index (CSI) merupakan indeks untuk mengukur tingkat kepuasan konsumen berdasarkan atribut-atribut tertentu. Menurut Dixon (1991) terdapat empat langkah dalam perhitungan CSI, yaitu : menentukan Mean Importance Score (MIS) dan Mean Satisfaction Score (MSS), membuat Weight Factors (WF) dan Weight Score (WS), Menghitung Weighted Total (WT), Menentukan CSI. Berdasarkan kuesioner yang disebar maka diperoleh tabel penilaian responden berdasarkan tingkat kepentingan yang nilai rata-ratanya dapat dipergunakan untuk menentukan MIS, kemudian diperoleh juga tabel penilaian responden berdasarkan tingkat kinerja yang nilai rata-ratanya dapat dipergunakan untuk menentukan MSS. Hasil CSI Kawasan SCBD adalah $78,7 \%$.

Tabel 1. Tabel Nilai MIS, MSS, WF, WS, WT, dan CSI

\begin{tabular}{|c|c|c|c|c|}
\hline INC & MIS & MSS & WF & WS \\
\hline AA1 & 4.800 & 4.292 & 1.616 & 6.936 \\
\hline AA2 & 4.800 & 4.369 & 1.616 & 7.060 \\
\hline AA3 & 4.800 & 4.323 & 1.616 & 6.98 \\
\hline AA4 & 5.000 & 4.062 & 1.683 & 6.836 \\
\hline AA5 & 4.431 & 3.985 & 1.492 & 5.943 \\
\hline AA6 & 5.000 & 4.092 & 1.683 & 6.888 \\
\hline AA7 & 5.000 & 4.057 & 1.683 & 6.829 \\
\hline AB1 & 5.000 & 4.277 & 1.683 & 7.199 \\
\hline AB2 & 5.000 & 4.262 & 1.683 & 7.173 \\
\hline AB3 & 4.800 & 4.277 & 1.616 & 6.911 \\
\hline AB4 & 4.215 & 3.923 & 1.419 & 5.567 \\
\hline AB5 & 5.000 & 4.108 & 1.683 & 6.914 \\
\hline AB6 & 3.585 & 4.108 & 1.207 & 4.957 \\
\hline AC1 & 4.600 & 4.062 & 1.549 & 6.289 \\
\hline AC2 & 4.800 & 4.092 & 1.616 & 6.612 \\
\hline $\mathrm{AC} 3$ & 4.800 & 4.231 & 1.616 & 6.836 \\
\hline AC4 & 4.800 & 4.062 & 1.616 & 6.563 \\
\hline AC5 & 4.400 & 3.969 & 1.481 & 5.879 \\
\hline AC6 & 4.400 & 3.969 & 1.481 & 5.879 \\
\hline AC7 & 4.185 & 3.785 & 1.409 & 5.331 \\
\hline AD1 & 4.585 & 4.169 & 1.543 & 6.434 \\
\hline AD2 & 3.985 & 3.892 & 1.341 & 5.221 \\
\hline AD3 & 4.385 & 4.123 & 1.47 & 6.08 \\
\hline
\end{tabular}

\begin{tabular}{|c|c|c|c|c|}
\hline & IIS & MSS & WF & ws \\
\hline AD4 & 3.815 & 3.585 & 1.284 & 4.6 \\
\hline AD5 & 215 & 3.714 & 1.419 & 5.2 \\
\hline AD6 & 4.600 & 3.800 & 1.549 & 8 \\
\hline AD7 & 000 & 800 & 347 & \\
\hline D8 & 415 & .029 & 1.486 & \\
\hline AD9 & 415 & 3.829 & 1.486 & \\
\hline AD10 & 15 & 3.829 & 1.486 & \\
\hline AD11 & 4.800 & 4.057 & 1.616 & 0. \\
\hline AD12 & 4.615 & 3.785 & 1.554 & \\
\hline AD13 & 4.785 & 492 & 1.611 & \\
\hline AD14 & 4.600 & 3.600 & 1.549 & \\
\hline AD15 & 015 & .743 & 1.352 & \\
\hline AE1 & & 846 & 1.543 & \\
\hline AE2 & 431 & 3.662 & 1.492 & 5.4 \\
\hline AE3 & 4.800 & 3.846 & 1.616 & 6.2 \\
\hline AE4 & 4.615 & 3.831 & 1.554 & 5.9 \\
\hline AE5 & 4.015 & 3.769 & 1.352 & \\
\hline AE6 & 4.215 & 3.677 & 1.419 & 5.2 \\
\hline AE7 & 4.815 & 3.912 & 1.621 & \\
\hline AE8 & 4.000 & 3.862 & 1.347 & \\
\hline AE9 & 4.800 & 3.938 & 1.616 & \\
\hline $\mathrm{AE} 1$ & 4.600 & 3.969 & 1.549 & \\
\hline I & 4.215 & 3.765 & 1.41 & \\
\hline
\end{tabular}

\begin{tabular}{|c|c|c|c|c|}
\hline CODING & MIS & MSS & WF & WS \\
\hline AF2 & 4.400 & 4.057 & 1.481 & 6.009 \\
\hline AF3 & 4.400 & 4.114 & 1.481 & 6.094 \\
\hline AF4 & 4.200 & 3.971 & 1.414 & 5.615 \\
\hline AF5 & 4.185 & 3.971 & 1.409 & 5.594 \\
\hline AF6 & 4.600 & 4.000 & 1.549 & 6.194 \\
\hline AF7 & 4.600 & 3.943 & 1.549 & 6.106 \\
\hline AF8 & 4.185 & 3.971 & 1.409 & 5.594 \\
\hline AF9 & 4.415 & 3.686 & 1.486 & 5.478 \\
\hline AF10 & 4.585 & 3.886 & 1.543 & 5.997 \\
\hline AF11 & 4.385 & 3.686 & 1.476 & 5.440 \\
\hline AF12 & 4.785 & 3.831 & 1.611 & 6.170 \\
\hline AG1 & 4.785 & 3.857 & 1.611 & 6.212 \\
\hline AG2 & 3.985 & 3.743 & 1.341 & 5.020 \\
\hline AG3 & 4.400 & 3.771 & 1.481 & 5.586 \\
\hline AG4 & 4.231 & 3.886 & 1.424 & 5.534 \\
\hline AG5 & 4.185 & 3.743 & 1.409 & 5.272 \\
\hline AH1 & 4.800 & 3.738 & 1.616 & 6.041 \\
\hline AH2 & 4.800 & 3.908 & 1.616 & 6.314 \\
\hline AH3 & 4.800 & 3.923 & 1.616 & 6.339 \\
\hline $\mathrm{AH} 4$ & 4.185 & 3.846 & 1.409 & 5.418 \\
\hline TAL MIS & 106.37 & & & \\
\hline & 393.57 & & & \\
\hline & 78.71 & & & \\
\hline
\end{tabular}

Sumber: Olahan Data Penulis, 2020 
Tabel 2. Tabel Nilai MIS, MSS, WF, WS, WT, dan CSI

Responden Building Manager \& Tenant Temporer

\begin{tabular}{|r|r|r|r|r|}
\hline \multicolumn{1}{|c|}{ CODING } & \multicolumn{1}{c}{ MIS } & \multicolumn{1}{c|}{ MSS } & \multicolumn{1}{c|}{ WF } & \multicolumn{1}{l|}{ WS } \\
\hline AA1 & 4.829 & 4.257 & 1.614 & 6.870 \\
\hline AA2 & 4.829 & 4.314 & 1.614 & 6.962 \\
\hline AA3 & 4.829 & 4.371 & 1.614 & 7.054 \\
\hline AA4 & 5.000 & 4.057 & 1.671 & 6.779 \\
\hline AA5 & 4.486 & 3.971 & 1.499 & 5.954 \\
\hline AA6 & 5.000 & 4.114 & 1.671 & 6.875 \\
\hline AA7 & 5.000 & 4.057 & 1.671 & 6.779 \\
\hline AB1 & 5.000 & 4.314 & 1.671 & 7.209 \\
\hline AB2 & 5.000 & 4.229 & 1.671 & 7.066 \\
\hline AB3 & 4.829 & 4.314 & 1.614 & 6.962 \\
\hline AB4 & 4.257 & 3.971 & 1.423 & 5.650 \\
\hline AB5 & 5.000 & 4.200 & 1.671 & 7.018 \\
\hline AB6 & 3.600 & 4.200 & 1.203 & 5.053 \\
\hline AC1 & 4.657 & 4.057 & 1.556 & 6.314 \\
\hline AC2 & 4.829 & 4.143 & 1.614 & 6.685 \\
\hline AC3 & 4.829 & 4.200 & 1.614 & 6.777 \\
\hline AC4 & 4.771 & 4.114 & 1.595 & 6.561 \\
\hline AC5 & 4.486 & 3.943 & 1.499 & 5.911 \\
\hline AC6 & 4.486 & 3.943 & 1.499 & 5.911 \\
\hline AC7 & 4.200 & 3.800 & 1.404 & 5.334 \\
\hline AD1 & 4.600 & 4.171 & 1.537 & 6.413 \\
\hline AD2 & 4.029 & 3.771 & 1.346 & 5.078 \\
\hline AD3 & 4.429 & _. 3.943 & 1.480 & 5.835 \\
\hline
\end{tabular}

\begin{tabular}{|c|c|c|c|c|}
\hline ODING & MIS & MSS & WF & WS \\
\hline$\overline{A D 4}$ & 3.886 & 3.629 & 1.299 & 4.712 \\
\hline AD5 & 257 & 3.714 & 1.423 & 5.28 \\
\hline AD6 & 657 & 3.800 & 1.556 & 5.914 \\
\hline AD7 & 1.029 & 3.800 & 1.346 & 5.116 \\
\hline AD8 & 4.486 & 4.029 & 1.499 & $6.03 \mathrm{~s}$ \\
\hline AD9 & 4.486 & 3.829 & 1.499 & 5.739 \\
\hline AD10 & 4.486 & 3.829 & 1.499 & 5.739 \\
\hline AD11 & 4.829 & 4.057 & 1.614 & 6.547 \\
\hline AD12 & 4.657 & 3.971 & 1.556 & 6.181 \\
\hline AD13 & 4.771 & 286 & 1.595 & 5.239 \\
\hline AD14 & 600 & 600 & 1.537 & 5.534 \\
\hline AD15 & 4.086 & 3.743 & 1.365 & 5.111 \\
\hline AE1 & 4.600 & 3.629 & 1.537 & 5.578 \\
\hline AE2 & 4.486 & 3.429 & 1.499 & 5.140 \\
\hline AE3 & 4.829 & 3.629 & 1.614 & 5.855 \\
\hline AE4 & 4.657 & 3.629 & 1.556 & 5.647 \\
\hline AE5 & 4.000 & 657 & 1.337 & 4.889 \\
\hline AE6 & 4.314 & 3.543 & 1.442 & 5.108 \\
\hline AE7 & 4.829 & 3.886 & 1.614 & 6.270 \\
\hline AE8 & 4.086 & 3.771 & 1.365 & 5.150 \\
\hline AE9 & 4.829 & 3.657 & 1.614 & 5.901 \\
\hline AE10 & 4.657 & 3.914 & 1.556 & 6.092 \\
\hline AF1 & -4.314 & 3.657] & 442 & 5.27 \\
\hline
\end{tabular}

\begin{tabular}{|c|c|c|c|c|}
\hline CODING & MIS & MSS & WF & ws \\
\hline AF2 & 4.429 & 4.057 & 1.480 & 6.005 \\
\hline AF3 & 4.429 & 4.114 & 1.480 & 6.089 \\
\hline AF4 & 4.257 & 3.971 & 1.423 & 5.650 \\
\hline AF5 & 4.200 & 3.971 & 1.404 & 5.574 \\
\hline AF6 & 4.600 & 4.000 & 1.537 & 6.149 \\
\hline AF7 & 4.600 & 3.943 & 1.537 & 6.061 \\
\hline AF8 & 4.257 & 3.971 & 1.423 & 5.650 \\
\hline AF9 & 4.429 & 3.686 & 1.480 & 5.455 \\
\hline AF10 & 4.600 & 3.886 & 1.537 & 5.973 \\
\hline AF11 & 4.429 & 3.686 & 1.480 & 5.455 \\
\hline AF12 & 4.771 & 3.514 & 1.595 & 5.604 \\
\hline AG1 & 4.771 & 3.857 & 1.595 & 6.151 \\
\hline AG2 & 4.029 & 3.743 & 1.346 & 5.039 \\
\hline AG3 & 4.429 & 3.771 & 1.480 & 5.582 \\
\hline AG4 & 4.314 & 3.886 & 1.442 & 5.602 \\
\hline AG5 & 4.200 & 3.743 & 1.404 & 5.254 \\
\hline AH1 & 4.829 & 3.800 & 1.614 & 6.132 \\
\hline AH2 & 4.829 & 3.971 & 1.614 & 6.409 \\
\hline AH3 & 4.829 & 3.857 & 1.614 & 6.224 \\
\hline $\mathrm{AH} 4$ & 4.200 & 3.800 & 1.404 & 5.334 \\
\hline TOTAL MIS & 299.30 & & & \\
\hline WT & 390.50 & & & \\
\hline CSI & 78.10 & & & \\
\hline
\end{tabular}

Sumber: Olahan Data Penulis, 2020

Tabel 3. Tabel Nilai MIS, MSS, WF, WS, WT, dan CSI Responden Visitor

\begin{tabular}{|l|r|r|r|r|}
\hline CODING & \multicolumn{1}{c}{ MIS } & \multicolumn{1}{c}{ MSS } & \multicolumn{1}{l|}{ WF } & \multicolumn{1}{l|}{ WS } \\
\hline AA1 & 4.767 & 4.333 & 2.637 & 11.429 \\
AA2 & 4.767 & 4.433 & 2.637 & 11.692 \\
AA3 & 4.767 & 4.267 & 2.637 & 11.253 \\
AA4 & 5.000 & 4.067 & 2.767 & 11.250 \\
AA5 & 4.367 & 4.000 & 2.416 & 9.664 \\
AA6 & 5.000 & 4.067 & 2.767 & 11.250 \\
AB1 & 5.000 & 4.233 & 2.767 & 11.712 \\
AB2 & 5.000 & 4.300 & 2.767 & 11.896 \\
AB3 & 4.767 & 4.233 & 2.637 & 11.165 \\
AB4 & 4.167 & 3.867 & 2.305 & 8.914 \\
AB5 & 5.000 & 4.000 & 2.767 & 11.066 \\
AB6 & 3.567 & 4.000 & 1.973 & 7.894 \\
AC1 & 4.533 & 4.067 & 2.508 & 10.200 \\
AC2 _-_ & 4.767 & 4.033 & 2.637 & 10.638 \\
\hline
\end{tabular}

\begin{tabular}{|l|r|r|r|r|}
\hline \multicolumn{1}{|c}{ CODING } & \multicolumn{1}{c}{ MIS } & \multicolumn{1}{c}{ MSS } & \multicolumn{1}{c|}{ WF } & \multicolumn{1}{c|}{ WS } \\
\hline AC3 & 4.767 & 4.267 & 2.637 & 11.253 \\
AC4 & 4.833 & 4.000 & 2.674 & 10.697 \\
AC5 & 4.300 & 4.000 & 2.379 & 9.517 \\
AC6 & 4.300 & 4.000 & 2.379 & 9.517 \\
AC7 & 4.167 & 3.767 & 2.305 & 8.684 \\
AD1 & 4.567 & 4.167 & 2.527 & 10.528 \\
AD2 & 3.933 & 4.033 & 2.176 & 8.778 \\
AD3 & 4.333 & 4.333 & 2.398 & 10.390 \\
AD4 & 3.733 & 3.533 & 2.066 & 7.299 \\
AD12 & 4.567 & 3.567 & 2.527 & 9.012 \\
AD13 & 4.800 & 3.733 & 2.656 & 9.915 \\
AE1 & 4.567 & 4.100 & 2.527 & 10.360 \\
AE2 & 4.367 & 3.933 & 2.416 & 9.503 \\
AE3 & 4.767 & 4.100 & 2.637 & 10.813 \\
\hline
\end{tabular}

\begin{tabular}{|l|r|r|r|r|}
\hline CODING & \multicolumn{1}{c}{ MIS } & \multicolumn{1}{c|}{ MSS } & \multicolumn{1}{l|}{ WF } & \multicolumn{1}{l|}{ WS } \\
\hline AE4 & 4.567 & 4.067 & 2.527 & 10.275 \\
AE5 & 4.033 & 3.900 & 2.232 & 8.703 \\
AE6 & 4.100 & 3.833 & 2.269 & 8.696 \\
AE8 & 3.900 & 3.967 & 2.158 & 8.560 \\
AE9 & 4.767 & 4.267 & 2.637 & 11.253 \\
AE10 & 4.533 & 4.033 & 2.508 & 10.117 \\
AF1 & 4.100 & 3.900 & 2.269 & 8.847 \\
AF12 & 4.800 & 4.200 & 2.656 & 11.155 \\
AH1 & 4.767 & 3.667 & 2.637 & 9.670 \\
AH2 & 4.767 & 3.833 & 2.637 & 10.110 \\
AH3 & 4.767 & 4.000 & 2.637 & 10.550 \\
AH4 & 4.167 & 3.900 & 2.305 & 8.991 \\
\hline TOTAL MIS & $\mathbf{1 8 0 . 7 3}$ & \multicolumn{3}{|l}{} \\
WT & $\mathbf{4 0 3 . 2 1}$ \\
CSI & $\mathbf{8 0 . 6 4}$ & \\
\hline
\end{tabular}

Sumber: Olahan Data Penulis, 2020

Apabila dibagi menjadi tingkat kepuasan building manager dan visitor, maka hasil yang diperoleh untuk CSI Building Manager dan Tenant Temporer adalah 78,1\%. CSI untuk Visitor adalah $80,6 \%$. SCBD tetap berusaha menyediakan fasilitas pengelolaan sesuai standard kepada visitor dan tenant-tenant di kawasan untuk tetap menjaga performa yang baik dan mempertahankan keterikatan dengan stakeholder terkait.

\begin{tabular}{|c|c|}
\hline CSI INDEX & $78.7 \%$ * \\
\hline 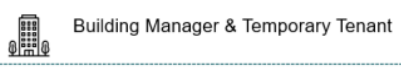 & $78.1 \%$ \\
\hline 路 Visitor & $80.6 \%$ \\
\hline
\end{tabular}

Gambar 4. CSI Index Keseluruhan, Building Manager \& Tenant Temporer, Visitor Sumber: Olahan Data Penulis, 2020

\section{Analisa Performa Faktor dan Atribut Faktor}

Performa pelayanan tersebut memiliki beberapa faktor yang dinilai berdasarkan point-point pelayanannya, antara lain kebersihan, keindahan, kenyamanan, kemudahan, keamanan, keselamatan, keberlanjutan, pencegahan Covid-19. 
Tabel 4. Tabel Analisa Performa Faktor

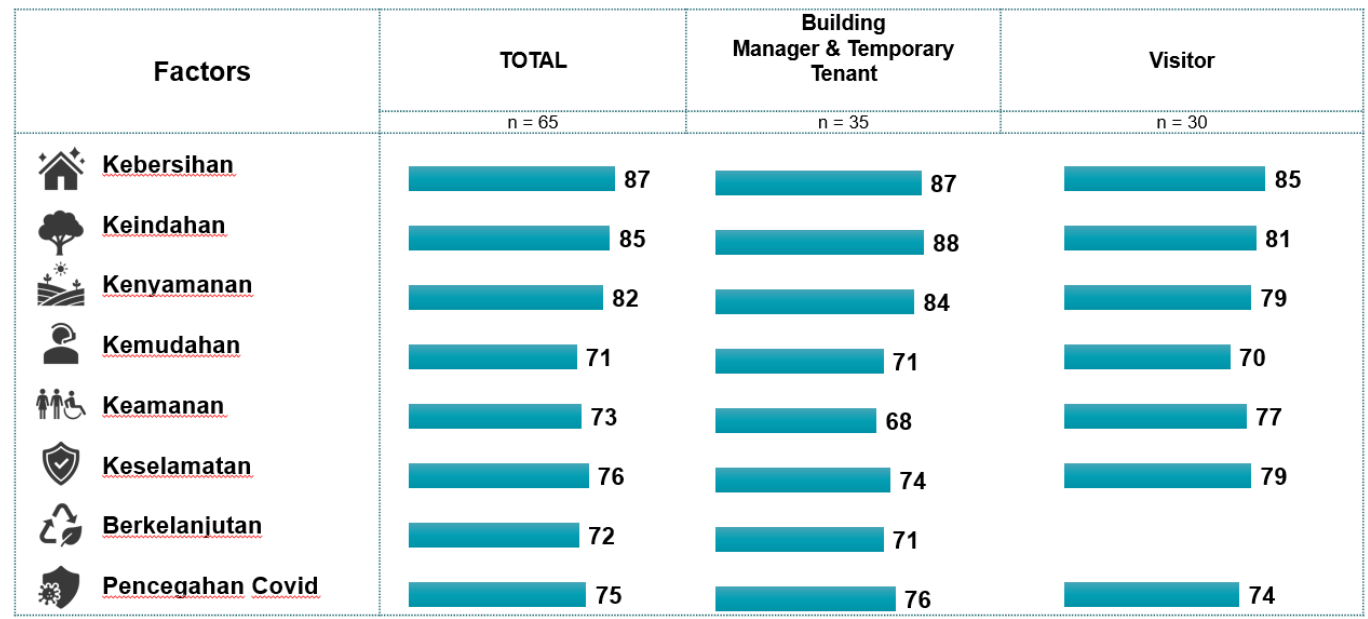

Sumber: Olahan Data Penulis, 2020

Penilaian performa kebersihan kawasan secara umum mendapatkan performa $87 \%$, terutama kebersihan pada pedestrian dan jalan raya. Performa faktor keindahan mencapai $85 \%$. Hal ini terlihat pada keindahan di atribut tanaman dan pepohonan yang terpelihara di kawasan SCBD. Kenyamanan merupakan salah satu faktor yang dianggap memiliki peran penting, atribut faktor kenyamanan pedestrian mendapatkan nilai performa 91\%, namun, dalam hal pengendalian kebisingan dari kegiatan konstruksi masih perlu ditingkatkan. Faktor kemudahaan mendapatkan nilai $71 \%$. Dalam hal ini, penanganan keluhan pelanggan mendapatkan nilai terendah, yaitu $34 \%$, sedangkan kemudahaan Akses Pedestrian mendapatkan nilai yang baik, yaitu $93 \%$. Penilaian faktor keamanan adalah $73 \%$, dengan performa tertinggi $81 \%$ pada kesigapan petugas keamanan, keamanan dalam menyeberang jalan dan keamanan di dalam bus kawasan. Namun, keramahan petugas masih menjadi catatan untuk perbaikan. Penilaian performa keselamatan adalah $76 \%$, dengan performa tertinggi $87 \%$ pada sosialisasi tanggap darurat yang baik, namun yang masih perlu diperhatikan adalah ketertiban pekerja konstruksi dan akses pejalan kaki ketika kegiatan pemeliharaan.

Dengan penilaian performa $72 \%$, faktor berkelanjutan masih menjadi faktor yang perlu ditingkatkan. Pemilahan sampah di ruang umum kawasan dianggap sudah baik, dinilai dengan $84 \%$. Sebaliknya, pengendalian kualitas suara, udara, dan air sungai dinilai perlu menjadi prioritas pengembangan dari faktor berkelanjutan. Performa pencegahan COVID-19 mendapatkan penilaian $75 \%$.

Tabel 5. Tabel Faktor Keunggulan dan Prioritas

\begin{tabular}{|c|c|}
\hline Faktor & Keunggulan \\
\hline Kebersihan & $\begin{array}{l}\text { - Kebersihan ruang umum kawasan } \\
\text { - Kebersihan pedestrian } \\
\text { - Kebersihan jalan raya } \\
\text { - Kebersihan tempat sampah di pedestrian }\end{array}$ \\
\hline Keindahan & $\begin{array}{l}\text { - Keasrian lingkungan } \\
\text { - Lansekap pedestrian yang indah } \\
\text { - Tanaman dan pepohonan terpelihara }\end{array}$ \\
\hline Kemudahan & $\begin{array}{l}\text { - Kemudahan akses pedestrian } \\
\text { - Kemudahan menemukan area penvebrangan orang (zebra cross) } \\
\text { - Kemudahan berkomunikasi dengan personil SCBD dalam pekeriaan }\end{array}$ \\
\hline Keselamatan & $\begin{array}{l}\text { - Keielasan sosialisasi prosedur tanggap darurat } \\
\text { - Koordinasi sosialisasi tanggap darurat }\end{array}$ \\
\hline
\end{tabular}

\begin{tabular}{|l|l|}
\hline Faktor & Prioritas \\
\hline Kenvamanan & - Pengendalian kebisingan kegiatan konstrukai \\
\hline Kemudahan & $\begin{array}{l}\text { - Informasi mengenai nomor telepon customer service SCBD } \\
\text { - Informasi mengenai customer sevice yang mudah dihubungi } \\
\text { - Penanganan keluhan pelanggan yang responsif } \\
\text { - Kemudahan akses informasi tekait fasilitas di ruang umum kawasan }\end{array}$ \\
\hline Keamanan & $\begin{array}{l}\text { - Jumlah petugas pengatur lalu lintas yang cukup } \\
\text { - Keramahan petugas keamanan }\end{array}$ \\
\hline Keselamatan & $\begin{array}{l}\text { - Keberadaan CCTV } \\
\text { - Ketertiban pekeria konstruksi dan petugas pemeliharaan lingkungan } \\
\text { - Kegiatan pemeliharaan tidak mengganggu akses pedestrian }\end{array}$ \\
\hline Berkelaniutan & $\begin{array}{l}\text { - Pengendalian kualitas suara (kebisingan) } \\
\text { - Pengendalian kualitas udara (polusi suara) } \\
\text { - Pengelolaan air sungai (water treatment plant) }\end{array}$ \\
\hline
\end{tabular}

Sumber: Olahan Data Penulis, 2020 


\section{Engagement Index}

Engagement Index memberikan indikator bagi pengelola kawasan seberapa jauh pelanggan memiliki keterikatan terhadap kawasan SCBD. Langkah untuk mengukur engagement index adalah dengan menghitung jumlah dari responden yang memberikan nilai $>3$, kemudian hasilnya dibagi dengan jumlah responden keseluruhan. Hasil dari engagement index Kawasan SCBD secara keseluruhan adalah 76.6\%. Kemudian untuk engagement index building manager dan tenant temporer adalah 76.2 dan untuk visitor adalah $78.4 \%$.

Tabel 6. Tabel TOP2BOX

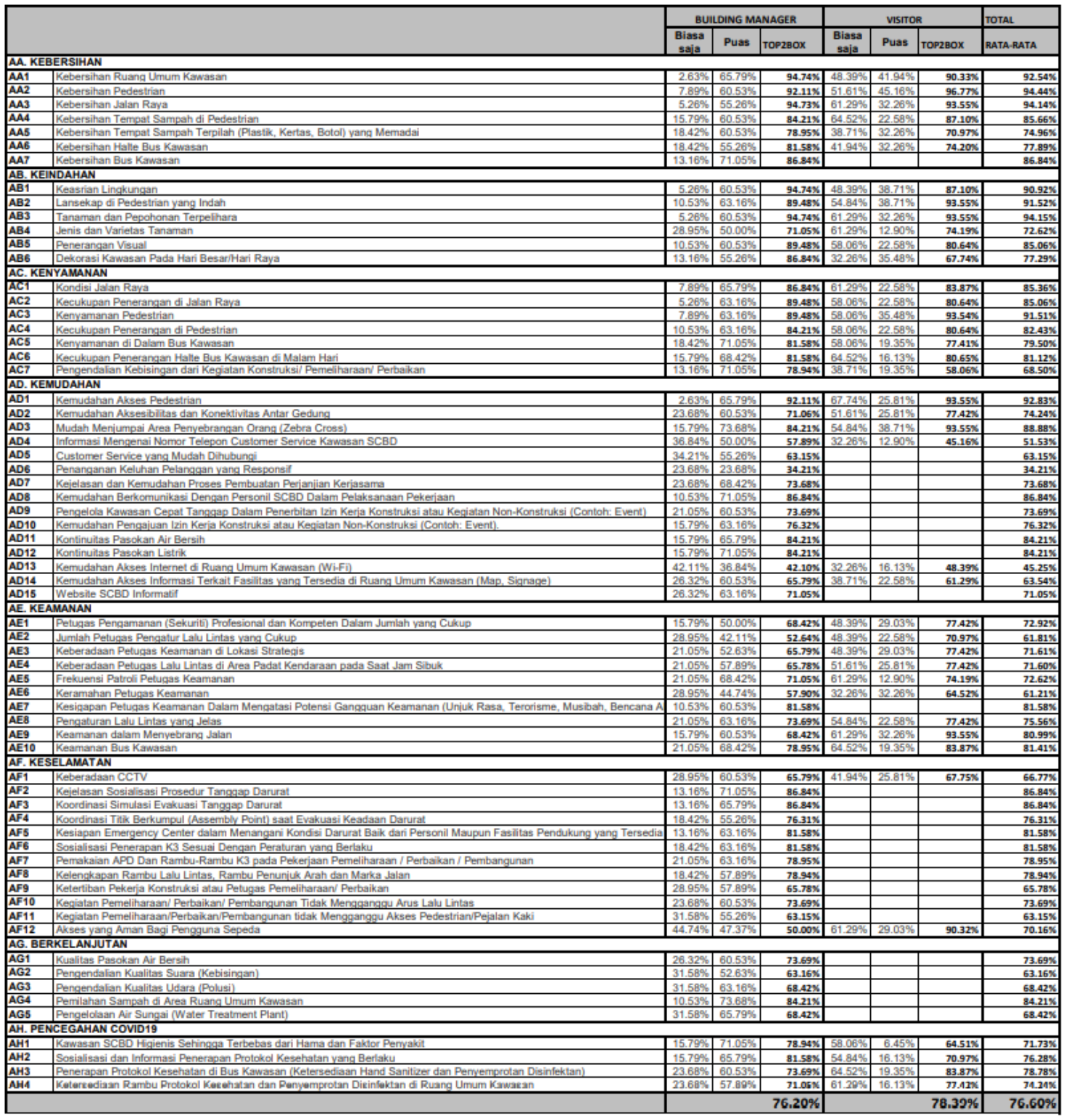

Sumber: Olahan Data Penulis, 2020

\section{KESIMPULAN DAN SARAN}

Di tengah situasi pandemi Covid-19 yang tidak menentu ini, CSI SCBD di tahun 2020 menunjukan nilai $78.7 \%$, dan masih ada di kategori memuaskan. Apabila dibagi menjadi tingkat kepuasan building manager dan visitor, maka hasil yang diperoleh untuk CSI building manager dan tenant temporer adalah $78,1 \%$, ada dalam kategori memuaskan. CSI untuk Visitor adalah 
$80,6 \%$, ada dalam kategori sangat memuaskan. SCBD tetap berusaha menyediakan fasilitas pengelolaan sesuai standard kepada visitor dan tenant-tenant di kawasan untuk tetap menjaga performa yang baik dan mempertahankan keterikatan dengan stakeholder terkait. Kemudian untuk mengetahui tingkat keterikatan tenant terhadap kawasan SCBD dapat melalui Engagement Index(EI) SCBD di tahun 2020 secara keseluruhan yang menunjukkan nilai $76.6 \%$, untuk El manager dan tenant temporer adalah $76.2 \%$, dan El visitor adalah $78.4 \%$. Seluruhnya masih sebanding dengan nilai CSI. Kemudian untuk performa dari setiap faktor dan atribut faktor yang paling unggul adalah kebersihan pedestrian, kebersihan jalan raya, dan terpeliharanya tanaman dan pepohonan. Sedangkan untuk penanganan keluhan pelanggan yang responsif, kemudahan akses internet di ruang umum kawasan, serta informasi mengenai nomor telepon customer service kawasan merupakan prioritas yang perlu diperbaiki lebih lanjut.

\section{REFERENSI}

Amstrong, G \& Philip, K. (2002). Dasar-dasar Pemasaran. Jilid 1, Alih Bahasa Alexander Sindoro dan Benyamin Molan. Jakarta: Penerbit Prenhalindo.

Anoraga, P. (2000). Psikologi Pemasaran. Jakarta: Penerbit Rineka Cipta.

Berman, B. and Joel R. E. (2003). Retail Management A Strategic Approach (Eighth Edition). New York: Maxwell MacMilan International Publishing Company.

Irawan, H. (2003). Prinsip-prinsip Kepuasan Pelanggan. Jakarta: Penerbit Elek Media Komputindo.

Kotler, P. \& Armstrong, G. (1999). Principle of Marketing. 8 th Edition. New Jersey: Prentice Hall.

Magi, A. \& Julander, C. R. (1996). Perceived service quality and customer satisfaction in a store performance framework. An empirical study of Swedish grocery retailers, Journal of Retailing and consumer services, 3(1) p.33-41.

Parasuraman, A. (2014). The Behaviorial Consequenses of Service Quality. New Jersey : Prentince Hall.

Prenshaw, P.J., Straughan, R.D., \& Anderson, R.D. (1998). The Relative Impact of Expectations, Performance, and Disconfirmation on Customer Satisfaction: The Moderating Role Of Buyer Expertise. In Proceedings of the Annual Meeting, Society for Marketing Advances, U.S.A., $65-70$

Setiadi, N. J. (2003). Perilaku Konsumen: Konsep dan Implikasinya untuk Strategi dan Penelitian Pemasaran. Jakarta: Prenada Media.

Wells, W. D. and Prensky, D. (2003). Consumer Behavior. 4th Edition. New York: John Wiley \& Sons.

SCBD_Peraturan_Kawasan_SCBD_Umum (2017)

https://ruangexcel.blogspot.com/2016/02/cara-cepat-uji-reabilitas.html

https://www.semestapsikometrika.com/2020/02/berapa-ukuran-sampel-idealdalam.html?m=1

https://teorionlinejurnal.wordpress.com/2012/08/20/menentukan-ukuran-sampel-menurutpara-ahli/

https://agungbudisantoso.com/cara-menghitung-tingkat-kepuasan-pelanggan/ 